\title{
Occupational asthma in an electronics factory
}

\author{
P SHERWOOD BURGE, W PERKS, I M O'BRIEN, R HAWKINS, AND M GREEN
}

From the Brompton Hospital, London SW3 6HP, UK

\begin{abstract}
Workers in a modern electronics factory were surveyed by questionnaire and lung function testing to see if there was evidence of widespread work-related respiratory symptoms. Of the responding workers exposed to solder flux fumes on the shop floor, $22 \%$ had work-related

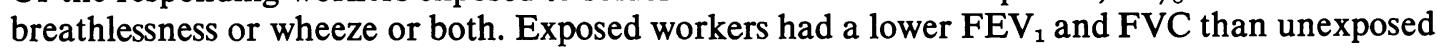
workers. Work-related rhinitis was also present in $22 \%$ of exposed workers. The most likely cause for these results is sensitivity to colophony fumes, released from solder flux during soldering. Levels of solder flux fume were below the threshold limit value in this factory during the survey.
\end{abstract}

Occupational asthma is being increasingly recognised in electronics factories (Paisley, 1969; Pepys et al, 1972; Burge et al, 1978). The first documented cases were caused by hypersensitivity to the fumes of toluene di-isocyanate, liberated from polyurethane-coated wires during soldering (Paisley, 1969; Pepys et al, 1972). Polyurethanecoated wires are generally used for coil winding, but they usually constitute a small proportion of the wires used, and soldering of them is confined to a few workers. More recently colophony (pine resin), the main constituent of electronic soldering flux, has been shown by provocation testing to cause occupational asthma in electronics factories (Fawcett et al, 1976; Burge et al, 1978). We have seen 15 workers from one factory with occupational asthma due to colophony (Burge et al, 1978). It seemed probable that these were not the only workers affected in the factory, and as the widespread occurrence of occupational asthma due to a common process in a major industry would have important social and medical consequences we undertook epidemiological studies in this factory to try to answer the following questions:

(1) How frequent were work-related respiratory symptoms in this factory?

(2) Is the present workforce a survivor population, the affected workers having left?

(3) What factors predispose to the development of respiratory disease in this factory?

The study was undertaken in three parts. This paper reports a survey of the prevalence of respiratory symptoms in the employees studied. The second study examined the records of the last 1339 workers leaving the factory to find the inci- dence of work-related respiratory disease as a reason for leaving. The third part is a case control study of 56 affected workers and 46 exposed unaffected workers to examine the role of atopy, smoking, work, family, and personal history of allergy in the development of work-related respiratory disease.

\section{Methods}

The surveyed factory has 924 employees consisting of office and stores staff and workers assembling printed circuit boards, chassis, and subassemblies for domestic audio equipment by mass production techniques. The factory is in two buildings separated by a road. Factory 1 has a main shop floor with 448 workers. There are four production lines assembling printed circuit boards, which are soldered automatically on flow solder machines using colophony flux with local exhaust extraction. There are six hand-wiring and soldering production lines where flux-cored solder containing colophony is used without local exhaust extraction. There are also two subassembly areas where wires are tinned by dipping the ends first in colophony flux and then in molten solder. These pots have had local exhaust extraction for one year. Some of these tinning operations use polyurethanecoated wires, which liberate fumes of toluene diisocyanate.

In factory 1 there is a separate stores area where several workers with occupational asthma due to colophony have been re-employed and have remained free of symptoms. The offices were separated from the production areas. 
Factory 2, with 194 workers on the shop floor, is similar except that there are no flow solder machines and the tinning pots have always had local exhaust extraction. There are many workers soldering on the production lines, however, with no local exhaust extraction.

The survey population was determined on 13 June 1977 when there were 924 people on the payroll. Of these, 37 were on a temporary evening shift that had been running for two months, and 10 were in training school in the first week of employment before entering the factory. Both of these groups were excluded, as were 10 workers who had left in the four days before the survey began (these 10 workers are included in the leavers' study). This left 867 employees who were sent a letter explaining the aims of the survey and asking them to participate. At this stage we excluded a further 30 workers who were away on holiday or training as they were likely to be distributed randomly between affected and unaffected groups. Workers away during the survey due to certified and unauthorised absence probably contain an excess of affected workers (table 8). Their exclusion is therefore likely to reduce the prevalence of work-related disease. The response rate (table 1) shows that there was much greater cooperation by shopfloor workers in factory 1 than factory 2 , due to an unforseen factor. The prevalence of work-related disease in the latter workers, however, was similar to the prevalence in factory 1 , so both groups have been analysed together (see results).

Workers were divided into three exposure groups for analysis. Those who regularly solder or tin probably inhale the colophony fumes that they make and are the highest exposure group (subsequently called solderers). All those who work on the shop floors but do not themselves solder or tin are exposed to the colophony fumes in the air and form an intermediate exposure group (other

Table 1 Survey population

\begin{tabular}{|c|c|c|c|c|}
\hline & $\begin{array}{l}\text { Factory 1: } \\
\text { All shop } \\
\text { floor }\end{array}$ & $\begin{array}{l}\text { Factory 2: } \\
\text { All shop } \\
\text { floor }\end{array}$ & $\begin{array}{l}\text { Factory 1: } \\
\text { Stores }\end{array}$ & $\begin{array}{l}\text { All } \\
\text { offices }\end{array}$ \\
\hline Survey population & 443 & 194 & 59 & 171 \\
\hline \multirow{3}{*}{$\begin{array}{l}\text { Away on holiday } \\
\text { Unauthorised absence } \\
\text { during survey } \\
\text { Certified sickness } \\
\text { during survey }\end{array}$} & 14 & 5 & 3 & 8 \\
\hline & 16 & 8 & 0 & 3 \\
\hline & 15 & 7 & 1 & 6 \\
\hline Available for survey & 398 & 174 & 55 & 154 \\
\hline Employees seen & 361 & 85 & 24 & 62 \\
\hline $\begin{array}{l}\text { Available employees } \\
\text { seen }\end{array}$ & $91 \%$ & $49 \%$ & $44 \%$ & $40 \%$ \\
\hline
\end{tabular}

shop floor workers). Workers in the offices and stores are a group whose exposure is small (subsequently called office workers).

During the survey the general factory air in the working area was analysed for solder flux fume concentration. The threshold limit value for solder flux fume is $0.1 \mathrm{mg} / \mathrm{m}^{3}$, and is measured as aldehyde content expressed as formaldehyde. Values obtained from static samples had a mean of 0.036 $\mathrm{mg} / \mathrm{m}^{3}$ with a range of $0.028-0.045 \mathrm{mg} / \mathrm{m}^{3}$. No toluene di-isocyanate was detected, but the limit of sensitivity of the measurement was $0.01 \mathrm{ppm}$ (TLV $0.02 \mathrm{ppm}$ ). Previous personal sampling of air in the breathing zone of solderers and tinners in this factory has always shown aldehyde concentrations below the TLV.

The survey was carried out on three consecutive work days. Fourteen trained interviewers completed the questionnaire based on that of the MRC (1976). After the questions on breathlessness and wheeze two additional questions were asked:

(1) Is your (breathlessness/wheeze) better at the weekend?

(2) Is your (breathlessness/wheeze) better on holiday?

All those who had either wheeze or breathlessness that improved at the weekend (when the factory was closed) were classified as having work-related respiratory symptoms. The same questions were asked after questioning on rhinitis, sore eyes, and headache.

An attempt was made to check the reproducibility of the questionnaire by repeating 12 questions with a different interviewer $10-15$ days later. This was done in 95 workers giving positive answers the first time. There was a mean of 1.5 discords per worker, which were randomly distributed.

The employee's position of work was recorded on a factory plan and his or her height was measured (without shoes to the nearest centimeter below the actual height). FEV $_{1}$ and FVC were measured on a dry wedge spirometer (Vitalograph Ltd, Buckingham, England) by one of eight trained physiologists. Records were continued until there were two satisfactory forced expiratory curves in which the best two readings of $\mathrm{FEV}_{1}$ and FVC were within 0.2 litres of each other. The best reading was recorded and expressed as a percentage of predicted values (Cotes, 1975) with $10 \%$ deducted from the predicted values for Asians and Negroes who together comprised about $10 \%$ of the solderers and other shopfloor workers. The spirometers were all calibrated before the start of the survey and were re-calibrated each day. The time taken for the

.


carriage to traverse the paper (a nominal six seconds) had a mean of $6.1 \mathrm{~s} \pm 0.05 \mathrm{~s}$ SD. When calibrated with air all spirometers gave a slightly higher reading than predicted (mean $8.05 \% \pm 1.86$ at six litres capacity). There was therefore good reproducibility between machines, which were all free of leaks.

\section{Results}

Table 2 shows the characteristics of the respondants. The three exposure groups are reasonably matched for age and smoking, but not for sex. Analysis has therefore been carried out for men and women separately. The other shop floor workers and the office/store workers include $49 \%$ and $23 \%$ who have regularly soldered or tinned in the past. A few of these workers had been

Table 2 Characteristics of the survey population related to work position

\begin{tabular}{|c|c|c|c|}
\hline & Solderers & $\begin{array}{l}\text { Other shop } \\
\text { floor }\end{array}$ & Office \\
\hline Total number & 97 & 349 & 86 \\
\hline $\begin{array}{l}\text { Men } \\
\text { Women }\end{array}$ & $\begin{array}{l}0 \% \\
100 \%\end{array}$ & $\begin{array}{l}20 \% \\
80 \%\end{array}$ & $\begin{array}{l}55 \% \\
45 \%\end{array}$ \\
\hline $\begin{array}{l}\text { Age, mean } \pm 1 \text { SD } \\
\text { Length of employment } \\
\text { mean } \pm 1 \mathrm{SD}(\mathrm{yr})\end{array}$ & $\begin{array}{c}38 \cdot 5 \pm 14 \cdot 3 \\
4 \cdot 7 \pm 4 \cdot 4\end{array}$ & $\begin{array}{c}39 \cdot 7 \pm 12 \cdot 5 \\
6 \cdot 7 \pm 5 \cdot 2\end{array}$ & $\begin{array}{c}42 \cdot 2 \pm 12 \cdot 3 \\
8 \cdot 2 \pm 5 \cdot 9\end{array}$ \\
\hline $\begin{array}{l}\text { Workers who have } \\
\text { regularly soldered and } \\
\text { tinned in the past but } \\
\text { not now }\end{array}$ & & $49 \%$ & $23 \%$ \\
\hline $\begin{array}{l}\text { Regular smokers } \\
\text { Ex-smokers } \\
\text { Never smoked }\end{array}$ & $\begin{array}{l}48.5 \% \\
12.5 \% \\
39 \%\end{array}$ & $\begin{array}{l}46 \% \\
14 \% \\
40 \%\end{array}$ & $\begin{array}{l}51 \% \\
20 \% \\
29 \%\end{array}$ \\
\hline
\end{tabular}

moved from soldering or tinning because of workrelated respiratory symptoms.

The results of the MRC questions on breathlessness (table 3) show that symptoms were much more common in women than men irrespective of work place, with shortness of breath in $46 \%$ of all exposed women (solderers and other shop floor workers). Men on the shop floor reported breathlessness significantly more often than men in the office. Shortness of breath walking with other people of their own age on level ground occurred much more often in the exposed group. The factors associated with breathlessness have been calculated by three-way analysis of variance, dividing the work place into three groups, smoking into three groups (current smokers, exsmokers, and lifelong non-smokers) and breathlessness into two groups (breathless and not breathless). The results are shown in fig 1 , which shows that the site of work within the factory is the most important determinant of breathlessness. Smoking also contributed significantly.

Table 4 shows the prevalence of wheeze. Thirtyeight per cent of respondants reported wheezing or whistling in the chest at some time. This appeared unrelated to work place. Wheezing that improved at the weekend or on holiday, however, occurred in $18 \%$ of exposed workers. The factors associated with wheeze have been calculated in the same way as for breathlessness, and results are shown in fig 2.

The prevalence of work-related respiratory symptoms is $22 \%$ overall in solderers and other shop floor workers and $6 \%$ in those working in the offices (table 5). There was little difference

Table 3 Prevalence of breathlessness related to sex and workplace: total and \% respondants. (Percentages in parentheses)

\begin{tabular}{|c|c|c|c|c|c|}
\hline & \multicolumn{3}{|l|}{ Women } & \multicolumn{2}{|l|}{ Men } \\
\hline & Solderers & Other shop floor & Office & Other shop floor & Office \\
\hline Total & 97 & 280 & 39 & 69 & 47 \\
\hline Disabled by diseases other than heart and lung & $1(1)$ & $3(1)$ & & $1(1)$ & $1(2)$ \\
\hline Not breathless & $53(55)$ & $145(52)$ & $20(51)$ & $\begin{array}{l}G \\
49(71)\end{array}$ & $\begin{array}{l}\text { H } \\
43(91)\end{array}$ \\
\hline $\begin{array}{l}\text { Shortness of breath hurrying on level ground } \\
\text { or walking up a slight hill }\end{array}$ & $20(20 \cdot 5)$ & $81(29)$ & $14(36)$ & $\begin{array}{l}\text { I } \\
14(21)\end{array}$ & $\begin{array}{l}\mathrm{J} \\
2(4)\end{array}$ \\
\hline $\begin{array}{l}\text { Shortness of breath walking with other people } \\
\text { of same age on level ground }\end{array}$ & $\begin{array}{l}\text { A } \\
19(19 \cdot 5)\end{array}$ & $30(10 \cdot 5)$ & $2(5)$ & $4(6)$ & \\
\hline $\begin{array}{l}\text { Stopping for breath when walking at own } \\
\text { pace on level ground }\end{array}$ & $4(4)$ & $21(7 \cdot 5)$ & $3(8)$ & $1(1)$ & $1(2)$ \\
\hline Breathlessness better at weekend & $15(15)$ & $\mathrm{C}_{50(18)}$ & $\mathrm{D}_{2(5)}$ & $\begin{array}{l}K \\
10(14)\end{array}$ & $\mathbf{L}$ \\
\hline Breathlessness better on holiday & $18(19)$ & $\begin{array}{l}E \\
66(24)\end{array}$ & F $3(8)$ & $\begin{array}{l}M \\
11(16)\end{array}$ & $\mathbf{N}$ \\
\hline
\end{tabular}

A-B; C-D; E-F; I-J $\quad P<0.05$

G-H; K-L; M-N $\quad P<0.01$ 


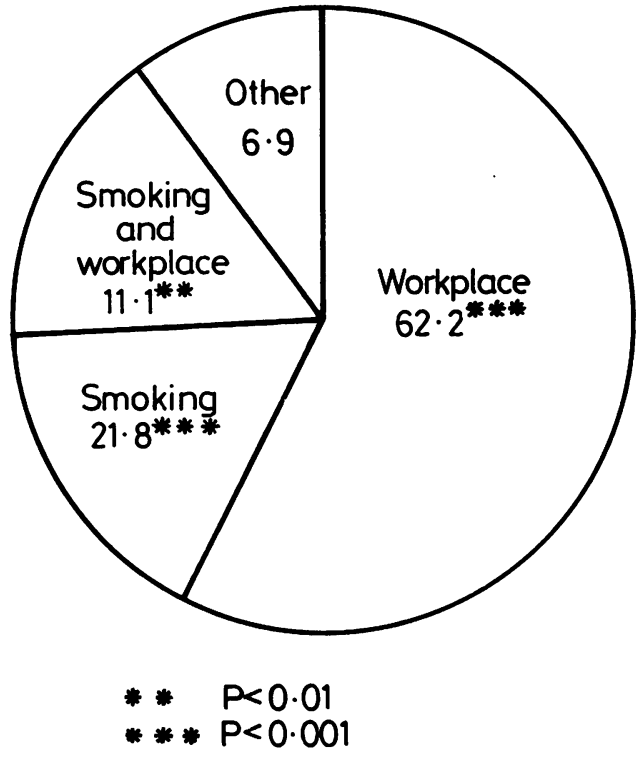

Fig 1 Determinants of breathlessness in workers with breathlessness better at the weekend.

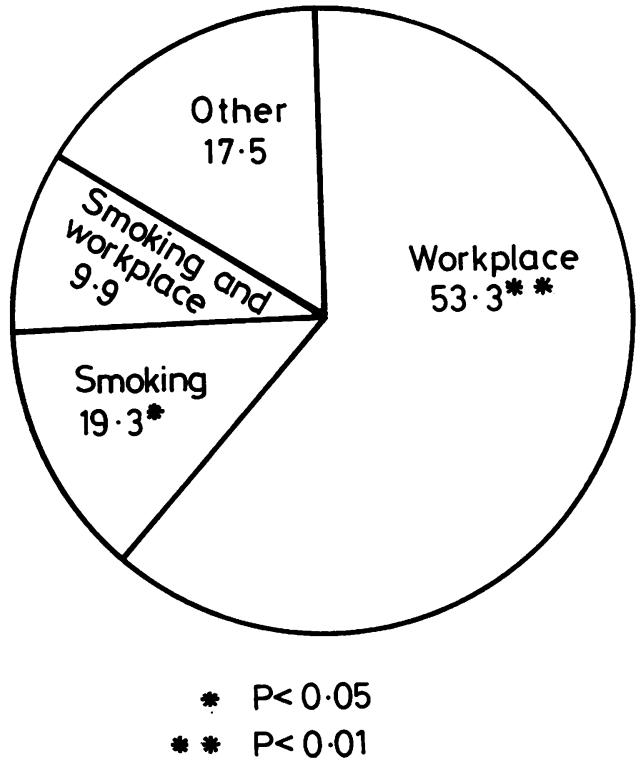

Fig 2 Determinants of wheeze in workers with wheeze better at the weekend.

Table 4 Prevalence of wheeze related to sex and workplace: total and \% respondants. (Percentages in parentheses)

\begin{tabular}{|c|c|c|c|c|c|}
\hline & \multicolumn{3}{|l|}{ Women } & \multicolumn{2}{|l|}{ Men } \\
\hline & Solderers & Other shop floor & Office & Other shop floor & Office \\
\hline Total & 97 & 280 & 39 & 69 & 47 \\
\hline No wheeze & $62(64)$ & 164 (59) & $22(56)$ & $46(67)$ & $35(74)$ \\
\hline Workers with wheezing or whistling in their chest & $35(36)$ & $116(41)$ & $17(44)$ & $23(33)$ & $12(26)$ \\
\hline Wheezing better at the weekend & $12(12)$ & $45(16)$ & $3(8)$ & $8(12)$ & $1(2)$ \\
\hline Wheezing better on holiday & $16(16)$ & $54(19)$ & $3(8)$ & $11(16)$ & $3(6)$ \\
\hline
\end{tabular}

between factories 1 and 2 for these results. Wheeze, better at the weekend, occurred in $15 \%$ and $14 \%$ of workers in factories 1 and 2 respectively. Breathlessness, better at the weekend, occurred in $18 \%$ and $13 \%$.

Table 6 shows the prevalence of rhinitis, sore eyes, headache, and rash. All except rash occurred more often in women. There was significantly more work-related rhinitis, sore eyes, headache, and rash in the exposed workers.

The results of lung function related to smoking and work place (table 7 ) show that the office workers have considerably superior lung function compared to the exposed workers. This effect is much less in the regular smokers who have lower FEV 1 and FVC than ex-smokers and non-smokers. Of exposed non-smokers, $27 \%$ have an FEV less than $85 \%$ of predicted, which is two standard deviations from the mean.

The diagnosis on the sickness certificates of
Table 5 Cases of work-related respiratory symptoms

\begin{tabular}{llll}
\hline & Solderers & Other shop floor & Office \\
\hline Total exposed & 97 & 349 & 86 \\
Dyspnoea only & 7 & 25 & 1 \\
Wheeze only & 4 & 18 & 3 \\
Wheeze and dyspnoea & 8 & 35 & 1 \\
Total cases & $19(20 \%)$ & $78(22 \%)$ & $5(6 \%)$ \\
\hline
\end{tabular}

those away during the survey with certified sickness (table 8) shows that five of 22 working on the shop floor were away with asthma; there was no sickness due to asthma in the office or store workers.

\section{Discussion}

Colophony has been used as a soldering flux since ancient times. It was described by Pliny in $77 \mathrm{AD}$, and was in use in the middle ages and is described 
Table 6 Prevalence of rhinitis-eye irritation, headache, and rash related to sex and workplace: total and $\%$ of respondants. (Percentages in parentheses)

\begin{tabular}{|c|c|c|c|c|c|}
\hline & \multicolumn{3}{|l|}{ Women } & \multicolumn{2}{|l|}{ Men } \\
\hline & Solderers & Other shop floor & Office & Other shop floor & Office \\
\hline Total & 97 & 280 & 39 & 69 & 47 \\
\hline $\begin{array}{l}\text { Do you suffer from an itchy, runny, or } \\
\text { blocked nose? }\end{array}$ & $45(46)$ & $111(40)$ & $17(44)$ & $21(30)$ & $18(38)$ \\
\hline Rhinitis better at the weekend & $\begin{array}{l}\text { A } \\
31(32)\end{array}$ & ${ }^{B} 61(22)$ & $\mathrm{C}_{3(8)}$ & $6(9)$ & $1(2)$ \\
\hline Do your eyes itch or water (at least once a week)? & $44(45)$ & $108(39)$ & $15(38)$ & $17(25)$ & $10(21)$ \\
\hline Eye irritation better at the weekend & $\begin{array}{l}\text { D } \\
29(30)\end{array}$ & $\mathrm{E}_{66(24)}$ & $F_{3(8)}$ & $9(13)$ & $2(4)$ \\
\hline $\begin{array}{l}\text { Do you suffer from headaches (at least once } \\
\text { a week)? }\end{array}$ & $\begin{array}{l}G \\
42(43)\end{array}$ & $\begin{array}{l}\text { H } \\
88(31)\end{array}$ & $14(36)$ & $19(28)$ & $7(15)$ \\
\hline Headache better at the weekend & $17(18)$ & $35(12 \cdot 5)$ & $4(10)$ & $I_{9(13)}$ & $\mathrm{J}_{1(2)}$ \\
\hline $\begin{array}{l}\text { Have you had a rash that you associate with } \\
\text { your work? }\end{array}$ & $11(11)$ & $35(12 \cdot 5)$ & $2(5)$ & $\begin{array}{l}K \\
13(19)\end{array}$ & $L_{2(4)}$ \\
\hline
\end{tabular}

A-C; B-C; D-F $\quad P<0.01$

E-F; G-H; I-J; K-L $\quad P<0.05$

Table 7 Lung function expressed as a percent of predicted (Cotes, 1975) related to smoking and workplace mean $\pm S E M$. (Percentages in parentheses)

\begin{tabular}{|c|c|c|c|c|c|c|c|c|c|}
\hline & \multicolumn{3}{|l|}{ Smokers } & \multicolumn{3}{|c|}{ Ex-smokers } & \multicolumn{3}{|c|}{ Non-smokers } \\
\hline & Solderers & $\begin{array}{l}\text { Other shop } \\
\text { floor }\end{array}$ & Office & Solderers & $\begin{array}{l}\text { Other shop } \\
\text { floor }\end{array}$ & Office & Solderers & $\begin{array}{l}\text { Other shop } \\
\text { floor }\end{array}$ & Office \\
\hline Total & 47 & 161 & 44 & 12 & 49 & 17 & 38 & 139 & 25 \\
\hline FEV $_{1}$ & $\begin{array}{r}92 \cdot 2 \\
\pm 2 \cdot 2\end{array}$ & $\begin{array}{r}92 \cdot 8 \\
\pm 1.4\end{array}$ & $\begin{array}{r}95 \cdot 2 \\
\pm 2 \cdot 4\end{array}$ & $\begin{array}{l}\mathrm{D} \\
91 \cdot 3 \\
\pm 6.5\end{array}$ & $\begin{array}{r}100.5 \\
\pm 1.8\end{array}$ & $\begin{array}{l}E \\
108 \cdot 6 \\
\pm 4 \cdot 2\end{array}$ & $\begin{array}{l}\text { H } \\
93.9 \\
\pm 2.7\end{array}$ & $\begin{array}{l}I_{93.4} \\
\pm 1.5\end{array}$ & $\begin{array}{l}\mathrm{J} \\
103 \cdot 1 \\
\pm 2 \cdot 5\end{array}$ \\
\hline FVC & $\begin{array}{r}98 \cdot 2 \\
\pm 2 \cdot 3\end{array}$ & $\begin{array}{r}99 \cdot 0 \\
\pm 1 \cdot 2\end{array}$ & $\begin{array}{r}98 \cdot 3 \\
\pm 2 \cdot 2\end{array}$ & $\begin{array}{l}F_{92.2} \\
\pm 5.9\end{array}$ & $\begin{array}{l}103 \cdot 6 \\
\pm 2 \cdot 1\end{array}$ & $\begin{array}{l}G \\
107 \cdot 1 \\
\pm 3 \cdot 2\end{array}$ & $\begin{array}{r}99 \cdot 3 \\
\pm 2 \cdot 4\end{array}$ & $\begin{array}{r}97 \cdot 6 \\
\pm 1 \cdot 3\end{array}$ & $\begin{array}{l}102 \cdot 1 \\
\pm 2 \cdot 3\end{array}$ \\
\hline $\begin{array}{l}\text { FEV } / F V C \\
\% \text { change } \\
\text { from predicted }\end{array}$ & $\begin{array}{l}A \\
-5.7 \\
\pm 1.0\end{array}$ & $\begin{array}{l}\text { B } \\
-5.6 \\
\pm 0.7\end{array}$ & $\begin{array}{l}\mathrm{C} \\
-2 \cdot 6 \\
\pm 1 \cdot 0\end{array}$ & $\begin{array}{l}-1 \cdot 6 \\
\pm 1 \cdot 6\end{array}$ & $\begin{array}{l}-2 \cdot 4 \\
\pm 1 \cdot 1\end{array}$ & $\begin{array}{l}+0.8 \\
\pm 1.6\end{array}$ & $\begin{array}{l}K \\
-5.0 \\
\pm 1.4\end{array}$ & $\begin{array}{l}L \\
-3.9 \\
\pm 0.6\end{array}$ & $\begin{array}{l}M \\
+0 \cdot 8 \\
\pm 1 \cdot 3\end{array}$ \\
\hline $\begin{array}{c}\mathrm{FEV}_{1}<75 \% \\
\text { predicted }\end{array}$ & $4(9)$ & $26(16)$ & $5(11)$ & $1(8)$ & & & $4(11)$ & $20(14)$ & $1(4)$ \\
\hline $\begin{array}{c}\mathrm{FEV}_{1}<85 \% \\
\text { predicted }\end{array}$ & $19(40)$ & $47(29)$ & $12(27)$ & $2(17)$ & $3(6)$ & $2(12)$ & $8(21)$ & $\mathrm{N}_{40 \text { (29) }}$ & $\mathrm{O}_{2(8)}$ \\
\hline
\end{tabular}

Table 8 Diagnosis on certification of workers away during the survey because of certificated sickness

\begin{tabular}{lcl}
\hline Diagnosis & Shop floor & Office and stores \\
\hline Asthma & 5 & 0 \\
Respiratory sickness & 1 & 1 \\
Non-respiratory disease & 16 & 6 \\
\hline
\end{tabular}

in a book of workshop recipes, Mappae Clavicula c 850 . This gives a recipe for a soldering cream containing two parts of axle grease, one part colophony resin, and an equal quantity of tin filings.
Since then colophony has been the standard flux. Since the 1930s activators have been added to colophony to accelerate its action. The electronics boom has increased the intensity of work enormously, which may explain why it has not been recognised as a cause of occupational asthma before.

In 20 of the 21 workers we have seen previously with occupational asthma due to colophony fumes (Burge et al, 1978) there has been a latent period of exposure ranging from two months to 25 years before symptoms developed. Most of these workers wheezed after a small exposure and developed 
patterns of asthma identical to those with soluble allergen-induced asthma. We therefore think that colophony fumes usually act as an allergen rather than an irritant. We have recently seen some workers with severe asthma from other causes, however, in whom it may act as an irritant.

We have studied a satisfactory sample of exposed workers on the shop floor of factory 1 , and as the workers in factory 2 give similar results this group is probably not biased. This gives data on 446 workers exposed to colophony fumes from soldering flux. We recognise that the 86 workers seen in the offices and stores, who have a small exposure to the fumes, are an unsatisfactory sample and represent a poor control group.

Many of the workers we have previously investigated for occupational asthma due to colophony fumes have not been solderers or tinners themselves (Burge et al, 1978), and one even worked in an office three floors above a factory making solder flux. In this survey symptoms are nearly as common in those exposed to the general factory environment as they are in the solderers and tinners themselves.

About one-third of our previous patients with solder flux asthma have not improved over one weekend away from work, improvement often taking one to six weeks. All of these said they were better on holiday. In this survey we have not included those who said their respiratory symptoms were better on holiday as being work-related, as factors contributing to their symptoms at home may also have been avoided on holiday. We are therefore likely to have underestimated the prevalence of work-related symptoms in this survey. Even so, the prevalence of work-related wheeze or breathlessness, or both, was $22 \%$ in all workers on the shop floor. Workrelated rhinitis was present in $9-32 \%$ of exposed workers. The question "do you ever have wheezing or whistling from your chest?" produced $38 \%$ positive answers. (It is unclear what this means, but most of those questioned did not describe anything resembling asthma.) There was a suprisingly high prevalence of breathlessness particularly in women, only about one-third of which we have classified as work-related. There are no good English female industrial controls for the MRC respiratory questionnaire. Waller and Brooks (1974) found the prevalence of breathlessness hurrying on level ground or walking up a slight hill to be $13.1 \%$ in 19 -year-old men and $27 \%$ in 19-year-old women but do not give figures for the more severe grades.
We have been unable to show an increased prevalence of respiratory disease in the solderers compared with the other shop floor workers. This may be partly due to the number of ex-solderers who were now in other jobs on the shop floor, or that the affected solderers had left, leaving a survivor population. For this reason the records of the last 1339 were studied to see if this was true. The results are shown in the accompanying paper (Perks et al, 1979).

The factory reported here clearly has a considerable problem with occupational respiratory disease. All the workers investigated by provocation testing from this factory have been sensitive to colophony, although fumes of toluene diisocyanate may be contributing to the respiratory disease. Further studies are needed in other factories to see how widespread the problem is.

We thank the following whose enthusiasm made this survey possible: $\mathbf{R}$ Bello, A Burge, C Burge, D Cramer, G Edge, M K Graham, W Hanmer, M Harries, C Hunter, E I'Ansom, D Johns, D Jones, M Lyddon, L Mansall, J Mitchell, A Morris, S Ollier, I Petheram, M Phillips, and J Wooden.

\section{References}

Burge, P S, Harries, M G, O'Brien, I M, and Pepys, $J$ (1978). Respiratory disease in workers exposed to solder flux fumes containing colophony (pine resin). Clinical Allergy, 8, 1-14.

Cotes, J E (1975). Lung Function, 3rd edn. Blackwell, Oxford.

Fawcett, I W, Newman Taylor, A J, and Pepys, J (1976). Asthma due to inhaled chemical agentsfumes from "Multicore" soldering flux and colophony resin. Clinical Allergy, 6, 577-585.

Paisley, D P G (1969). Isocyanate hazard from wire insulation; an old hazard in new guise. British Journal of Industrial Medicine, 26, 79-81.

Pepys, J, Pickering, C A C, Breslin, A B X, and Terry, D J (1972). Asthma due to inhalation of chemical agents-tolylene di-isocyanate. Clinical Allergy, 2, 225-236.

Perks, W H, Burge, P S, Rehahn, M, Green, M (1979). Work-related respiratory disease in employees leaving an electronics factory. Thorax, 34, 19-22.

Waller, R E, Brooks, A G F, and Adler, M W (1974). Respiratory symptoms and ventilatory capacity in a cohort of Londoners born in 1952-3. In Proceedings CEA-EPA-WHO International Symposium, Environment in Health, pp 4-12, Paris.

Requests for reprints to: Dr P S Burge, Brompton Hospital, London SW3 6HP. 